\title{
ETIKA KEILMUAN: Sebuah Kajian Filsafat Ilmu
}

\author{
Mokh. Sya'roni \\ Mahasiswa Program Doktor \\ Pascasarjana Universitas Islam Negeri (UIN) Walisongo \\ Semarang \\ e-mail: syaroni_1972@yahoo.com
}

\begin{abstract}
Scientific knowledge is knowledge which it self has acritical characteristic, rational, logical, objective and open. This is a must for a scientist to do so. But it is also a fundamental problem faced by scientist safter he built a strongsturdy building is theusability of sciences for human life. It cannot bedenied that science has brought people to wards a big change, but can science which is solid, strong, and fundamental to save human, or vice versa. Here is lies there sponsibility of a scientist. The development of science as science axiology embodiment requires properethicalvision to be applied. Man with science will be able to do anything they want, but consideration not only on what can bed one by humans. Which is more important in this context is the need for ethical consideration of what to do with the purpose of human kindness.
\end{abstract}

Abstrak: Pengetahuan ilmiah adalah pengetahuan yang di dalam dirinya memiliki karakteristik kritis, rasional, logis, objektif dan terbuka. Hal ini merupakan suatu keharusan bagi seorang ilmuwan untuk melakukannya. Namun selain itu juga masalah yang mendasar yang dihadapi ilmuwan setelah ia membangun suatu bangunan yang kokoh kuat adalah masalah kegunaan ilmu bagi kehidupan manusia. Memang tak dapat disangkal bahwa ilmu telah membawa manusia ke arah perubahan yang cukup besar, tetapi dapatkah ilmu yang kokoh, kuat, dan mendasar itu menjadi penyelamat manusia bukan sebaliknya.Di sinilah letak tanggung jawab seorang ilmuwan. Pengembangan ilmu pengetahuan sebagai perwujudan aksiologi ilmu mengharuskan visi etik yang tepat untuk diaplikasikan. Manusia dengan ilmu pengetahuan akan mampu berbuat apa saja yang diinginkan, namun pertimbangannya tidak hanya pada apa yang dapat diperbuat oleh manusia. Yang 
MOKH SYA'RONI:Etika Keilmuan

lebih penting pada konteks ini adalah perlunya pertimbangan etik apa yang harus dilakukan dengan tujuan kebaikan manusia.

Keywords: al-Quran, etika Islam, estetika, metaetika, ilmu.

\section{A. Pendahuluan}

Ilmu bukanlah merupakan pengetahuan yang datang begitu saja seperti barang yang sudah jadi dan datang dari dunia khayal. Akan tetapi ilmu merupakan suatu cara berpikir yang demikian rumit dan mendalam tentang suatu objek yang khas dengan pendekatan yang khas pula sehingga menghasilkan suatu kesimpulan yang berupa pengetahuan yang handal. Handal dalam arti bahwa sistem dan struktur ilmu dapat dipertanggungjawabkan secara terbuka. Ia terbuka untuk diuji oleh siapapun.

Ilmu merupakan salah satu dari buah pemikiran manusia dalam menjawab masalah-masalah kehidupan. Ilmu merupakan salah satu dari pengetahuan manusia. Untuk bisa menghargai ilmu sebagaimana mestinya sesungguhnya kita harus mengerti apakah hakikat ilmu itu sebenarnya. Dengan demikian maka pengertian yang mendalam terhadap hakikat ilmu, bukan saja akan mengikatkan apresiasi kita terhadap ilmu, namun juga membuka mata kita terhadap berbagai kekurangan. ${ }^{1}$

Ilmu yang merupakan produk kegiatan berpikir merupakan obor peradaban di mana manusia menemukan dirinya dan menghayati hidup dengan lebih sempurna. Berbagai peralatan dikembangkan manusia untuk meningkatkan kualitas hidupnya dengan jalan menerapkan pengetahuan yang diperolehnya. Proses penemuan dan penerapan itulah yang menghasilkan kapak dan batu zaman dulu sampai komputer hari ini. Berbagai masalah memasuki benak pemikiran manusia dalam menghadapi kenyataan hidup sehari-hari dan beragam buah pemikiran telah dihasilkan sebagai bagian dari 
sejarah kebudayaannya. Meskipun tampak betapa banyak dan beraneka ragamnya buah pemikiran itu, namun pada hakikatnya upaya manusia dalam memperoleh pengetahuan didasarkan pada tiga masalah pokok: Apakah yang ingin kita ketahui? Bagaimanakah cara kita memperoleh pengetahuan? Dan apakah nilai pengetahuan tersebut bagi kita?²

\section{B. Landasan Aksiologi Ilmu}

Pengetahuan ilmiah adalah pengetahuan yang di dalam dirinya memiliki karakteristik kritis, rasional, logis, objektif dan terbuka.Hal ini merupakan suatu keharusan bagi seorang ilmuwan untuk melakukannya. Namun selain itu juga masalah yang mendasar yang dihadapi ilmuwan setelah ia membangun suatu bangunan yang kokoh kuat adalah masalah kegunaan ilmu bagi kehidupan manusia. Memang tak dapat disangkal bahwa ilmu telah membawa manusia kearah perubahan yang cukup besar.akan tetapi dapatkah ilmu yang kokoh, kuat, dan mendasar itu menjadi penyelamat manusia bukan sebaliknya. Di sinilah letak tanggungjawab seorang ilmuwan. ${ }^{3}$

Pertanyaan selanjutnya adalah apakah kegunaan ilmu itu bagi manusia? Tak dapat disangkal bahwa ilmu telah banyak mengubah dunia dalam memberantas penyakit, kelaparan, kemiskinan dan berbagai wajah kehidupan yang duka.Apakah ilmu selalu merupakan berkat dan penyelamat bagi manusia? Dengan jalan mempelajari ilmu atom kita bisa memanfaatkan wujud tersebut sebagai sumber energi bagi keselamatan manusia, tetapi di pihak lain hal ini bisa juga berakibat sebaliknya, yakni membawa manusia kepada penciptaan bom atom yang menimbulkan malapetaka. Usaha memerangi kuman yang membunuh manusia sekaligus menghasilkan senjata kuman yang dipakai sebagai alat untuk membunuh untuk sesama manusia pula. Einstein mengeluh di hadapan mahasiswa California Institute of Technology, 
MOKH SYA'RONI:Etika Keilmuan

"Dalam peperangan ilmu menyebabkan manusia saling meracun dan saling menjagal. Dalam perdamaian dia membikin hidup manusia dikejar waktu dan penuh tak tentu...Mengapa ilmu yang amat indah ini, yang menghemat kerja dan membikin hidup lebih mudah, hanya membawa kebahagiaan yang sedikit sekali kepada manusia ?"4

Penerapan ilmu pengetahuan dan teknologi membutuhkan dimensi etis pada pertimbangan perkembangan ilmu pengetahuan dan teknologi itu sendiri.Menurut Amsal Bakhtiar tanggungjawab keilmuan menyangkut kegiatan maupun penggunaan ilmu pengetahuan dan teknologi. Ini berarti ilmuwan dalam mengembangkan ilmu pengetahuan dan teknologi harus memperhatikan kodrat dan martabat manusia, menjaga ekosistem, bertanggungjawab pada kepentingan umum, dan generasi mendatang, serta bersifat universal karena pada hakikatnya ilmu pengetahuan dan teknologi adalah untuk mengembangkan dan memperkokoh ekosistem manusia bukan untuk menghancurkan ekosistem tersebut.

Dalam konteks pengembangan ilmu, seorang ilmuwan harus memliki sikap ilmiah sebagai bagian intergral dari sifat ilmu. Hal ini disebabkan oleh karena sikap ilmiah adalah suatu sikap yang diarahkan untuk mencapai suatu pengetahuan ilmiah yang bersifat objektif. Sikap ilmiah bagi seorang ilmuwan bukanlah membahas tentang tujuan dari ilmu, melainkan bagaimana cara untuk mencapai suatu ilmu yang bebas dari prasangka pribadi dan dapat dipertanggungjawabkan secara sosial untuk melestarikan dan keseimbangan alam semesta ini, serta dapat dipertanggungjawabkan kepada Tuhan. Artinya selaras dengan kehendak manusia dan kehendak Tuhan.

Sikap ilmiah yang perlu dimiliki para ilmuwan itu antara lain adalah pertama tidak ada rasa pamrih (disinterestedness), artinya suatu sikap yang diarahkan untuk mencapai pengetahuan ilmiah yang objektif dengan menghilangkan pamrih atau kesenangan 
pribadi; kedua, bersikap selektif, yaitu suatu sikap yang tujuannya agar para ilmuwan mampu mengadakan pemilihan terhadap pelbagai hal yang dihadapi. Misalnya hipotesis yang beragam, metodologi yang masing-masing menunjukkan kekuatannya masingmasing, atau, cara penyimpulan yang satu cukup berbeda walaupun masing-masing menunjukkan akurasinya; ketiga, adanya rasa percaya yang layak baik terhadap kenyataan maupun terhadap alatalat indera serta budi (mind), keempat, adanya sikap yang berdasar pada suatu kepercayaan (belief) dan dengan merasa pasti (conviction) bahwa setiap pendapat atau teori yang terdahulu telah mencapai kepastian, kelima, adanya suatu kegiatan rutin bahwa seorang ilmuwan harus selalu tidak puas terhadap penelitian yang telah dilakukan, sehingga selalu ada dorongan untuk riset, dan riset sebagai aktivitas yang menonjol dalam hidupnya, dan akhirnya keenam, seorang ilmuwan harus memiliki sikap etis (akhlaq) yang selalu berkehendak untuk mengembangkan ilmu untuk kemajuan ilmu dan untuk kebahagiaan manusia, lebih khusus untuk pembangunan bangsa dan negara. ${ }^{5}$

\section{Etika dalam Aksiologi Ilmu}

Aksiologi ilmu terkait dengan persoalan nilai ilmu pengetahuan yang dalam kajian filsafat dapat diklasifikasikan ke dalam tiga jenis, yaitu :

\section{Nilai Logika:Benar-Salah}

Nilai logika disini, yaitu nilai mengenai benar atau salahnya tindakan/kejadian.Dalam hal ini nilai logika berkaitan dengan tindakan/kejadian yang dilakukan oleh seseorang. Sebagai contoh seorang siswa menjawab pertanyaan yang diajukan oleh guru, kemudian ia berhasil menjawab dengan benar, maka secara logika jawaban tersebut dianggap benar bukan baik, dan ketika jawabannya keliru maka secara logika jawaban tersebut dianggap salah bukan buruk. 
MOKH SYA'RONI:Etika Keilmuan

\section{Nilai Etika: Nilai tentang Baik dan Buruk}

Nilai etik/etika adalah nilai tenteng baik-buruk yang berkaitan dengan perilaku manusia.Jadi, kalu kita mengatakan etika orang itu buruk, bukan berarti wajahnya buruk, tetapi menunjuk perilaku orang itu buruk.Nilai etik adalah nilai moral.Jadi, moral yang di maksudkan disini adalah nilai moral sebagai bagian dari nilai.

\section{Nilai Estetika: Nilai tentang Indah-Jelek}

Estetika merupakan nilai yang berkaitan dengan keindahan, penampilan fisik, bukan nilai etik.Nilai estetika berkaitan dengan penampilan, sedangkan nilai etik atau buruk moral berkaitan dengan perilaku manusia.

Terkait dengan kajian etika, secara historis etika sebagai usaha filsafat lahir dari kehancuran moral dilingkungan kebudayaan Yunani 2500 tahun yang lalu. Karena pandangan-pandangan yang lama tentang baik dan buruk tidak lagi dipercayai,para filosof mempertanyakan kembali norma-norma dasar bagi kelakuan manusia, Situasi itu berlaku pada zaman sekarang juga,bahkan bagi kita masing-masing.Yang dipersoalkan bukan hanya apakah yang merupakan kewajiban saya dan apa yang tidak,melainkan manakah norma-norma untuk menentukan apa yang harus dianggap sebagai kewajiban.Untuk mencapai suatu pendirian dalam pergolakan pandangan-pandangan moral ini refleksi kritis etika diperlukan. ${ }^{6}$

Seperti halnya dengan banyak istilah yang menyangkut konteks ilmiah, istilah "etika" berasal dari bahasa Yunani kunoethos. Kata ethos dalam bentuk tunggal mempunyai banyak arti: tempat tinggal yang biasa; pada rumput, kandang; kebiasaan, adat; akhlak, watak; perasaan, sikap, cara berpikir. Dalam bentuk jamak (ta etha) artinya adalah: adat kebiasaan. Dan arti terakhir inilah menjadi latar belakang bagi terbentuknya istilah "etika" yang oleh filsuf Yunani besar Aristoteles (284-322 SM) sudah dipakai untuk menunjukkan filsafat moral. Jadi, kita membatasi diri pada asal-usul kata ini, maka 
MOKH. SYA'RONI:Etika Keilmuan

"etika" berarti: ilmu tentang apa yang biasa dilakukan atau ilmu tentang adat kebiasaan. ${ }^{7}$

Secara etimologis, ethic berarti system of moral principles ${ }^{8}$ atau a system of moral standard values ${ }^{9}$. Secara terminologi etika didefinisikan sebagai: the normatif science of the conduct of human being living societies. A science which judge this conduct to be right or wrong, to be good or bad. ${ }^{10}$ Secara singkat etika didefinisikan sebagai ilmu pengetahuan tentang kesusilaan (moral). ${ }^{11}$

Kata yang cukup dekat dengan "etika" adalah "moral". Kata terakhir ini berasal dari bahasa Latin mos(jamak: mores) yang berarti juga: kebiasaan, adat. Dalam bahasa Inggris dan banyak bahasa lain, termasuk bahasa Indonesia (pertama kali dimuat dalam Kamus Besar Bahasa Indonesia, 1988), kata mores masih dipakai dalam arti yang sama. Jadi, etimologi kata "etika" sama dengan etimologi kata "moral", karena keduanya berasal dari kata yang berarti adat kebiasaan. Hanya bahasa asalnya berbeda; yang pertama berasal dari bahasa Yunani, sedang yang kedua dari bahasa Latin.

Moral adalah ajaran-ajaran wejanganwejangan khutbahkhutbah patokan-patokan tentang bagaimana manusia harus hidup dan bertindak agar ia menjadi manusia yang baik. Sumber langsung ajaran moral dapat berupa ajaran agama, nasihat para bijak, orang tua, guru dan sebagainya. Pendek kata sumber ajaran moral meliputi agama, tradisi, adat-istiadat dan ideologi-ideologi tertentu. ${ }^{12}$

Sebagai sistem nilai, etika berarti nilai-nilai dan norma-norma moral yang menjadi pegangan bagi seseorang atau kelompok dalam mengatur tingkah lakunya. Dalam posisi inilah sebagai besar makna etika dipahami sehingga muncul istilah-istilah "Etika Islam", "Etika Budha”, "Etika Kristen”, dan sebagainya.

Dalam posisinya sebagai filsafat moral, etika memiliki kedudukan sebagai ilmu, bukan sebagai ajaran. Etika dan ajaran moral tidak berada di tingkat yang sama. Ajaran moral mengajarkan 
MOKH SYA'RONI:Etika Keilmuan

bagaimana kita hidup, sedangkan etika ingin mengetahui mengapa kita mengikuti ajaran moral tertentu atau bagaimana kita mengambil sikap yang bertanggungjawab ketika berhadapan dengan berbagai ajaran moral.

Etika sebagai filsafatmempelajari pandangan-pandangan, persoalan-persoalan yang berhubungan dengan masalah kesusilaan. Etika pada kajian filsafat ini sangat menarik perhatian para filosof dalam menanggapi makna etika secara lebih serius dan mendalam, sebagaimana yang dikemukakan oleh Aristoteles. Aristoteles dalam bukunya Etika Nikomacheia,menjelaskan tentang pembahasan etika kedalam dua hal penting,yaitu pertama,etika sebagai terminus techius. Pengertian etika dalam hal ini adalah ilmu pengetahuan yang mempelajari masalah perbuatan atau tindakan manusia. Kedua,etika dimaknai sebagai manner dan custom,dimana etika dipahami sebagai sesuatu yang berkaitan dengan tata cara dan kebiasaan (adat) yang melekat dalam kodrat manusia ( Inherent in human nature) yang terikat dengan pengertian " baik dan buruk" suatu tingkah laku atau perbuatan manusia. ${ }^{13}$

Etika mempunyai sifat yang sangat mendasar, yaitu sifat kritis.Etika mempersoalkan norma-norma yang dianggap berlaku, menyelidiki dasar norma-norma itu, mempersoalkan hak dari setiap lembaga seperti orang tua, negara, dan agama untuk memberi perintah atau larangan yang harus ditaati.Hak dan wewenang untuk menuntut ketaatan dari lembaga tersebut harus dan perlu dibuktikan. Dengan demikian, etika menuntut orang bersikap rasional terhadap semua norma. Sehingga etika akhirnya membantu manusia menjadi lebih otonom.

Otonomi manusia tidak terletak pada kebebasan dari segi norma dan tidak sama dengan kesewenang-wenangan, melainkan tercapai dalam kebebasan untuk mengakui norma-norma yang diyakininya sendiri sebagai kewajibannya. Dengan demikian, etika dibutuhkan sebagai pengantar pemikiran yang kritis, yang dapat 
membedakan antara apa yang sah dan yang tidak sah, membedakan apa yang baik dan apa yang tidak baik. Dengan demikian, etika memberikan kemungkinan kepada kita untuk mengambil sikap individual serta ikut menentukan arah perkembangan masyarakat.

Sebagai salah satu cabang aksiologi ilmu yang banyak membahas masalah nilai-baik atau buruk etika mengandung tiga pengertian:

Kata etika bisa dipakai dalam arti nilai-nilai atau norma-norma moral yang menjadi pegangan seseorang atau suatu kelompok dalam mengatur tingkah lakunya.

a. Etika berarti kumpulan asas atau nilai moral. Misalnya kode etik.

b. Etika merupakan ilmu tentang yang baik atau yang buruk. Etika baru menjadi ilmu bila kemungkinan-kemungkinan etis (asas-asas dan nilai-nilai tentang yang dianggap baik atau buruk) yang begitu saja diterima dalam suatu masyarakat seringkali tanpa disadari- menjadi bahan refleksi bagi suatu penelitian sistematis dan metodis. Etika dalam hal ini sama dengan filsafat moral. ${ }^{14}$

Etika sebagai ilmu yang menyelidiki tentang tingkah laku moral dapat dihampiri berdasarkan atas tiga macam pendekatan, yaitu: Etika Deskriptif, Etika Normatif, dan Metaetika.

a. Etika deskriptif adalah cara melukiskan tingkah laku moral dalam arti luas seperti: adat kebiasaan, anggapan tentang baik atau buruk, tindakan yang diperbolehkan atau tidak. Etika deskriptif mempelajari moralitas yang terdapat pada individu, kebudayaan atau sub-kultur tertentu. Oleh karena itu etika deskriptif ini tidak memberikan penilaian apa pun, ia hanya memaparkan. Etika deskriptif lebih bersifat netral. Misalnya: Penggambaran tentang adat mengayau kepala pada suku primitif. 
MOKH SYA'RONI:Etika Keilmuan

b. Etika normatif mendasarkan pendiriannya atas norma. Ia dapat mempersoalkan norma yang diterima seseorang atau masyarakat secara lebih kritis. Ia bisa mempersoalkan apakah norma itu benar atau tidak. Etika normatif berarti sistemsistem yang dimaksudkan untuk memberikan petunjuk atau penuntun dalam mengambil keputusan yang menyangkut baik atau buruk. Etika normatif ini dibagi menjadi dua, yaitu:

1) Etika umum, yang menekankan pada tema-tema umum seperti: Apa yang dimaksud norma etis? Mengapa norma moral mengikat kita? Bagaimana hubungan antara tanggungjawab dengan kebebasan?

2) Etika khusus, upaya untuk menerapkan prinsip-prinsip etika umum ke dalam perilaku manusia yang khusus. Etika khusus juga dinamakan etika terapan.

c. Metaetika, yaitu kajian etika yang ditujukan pada ungkapanungkapan etis. Bahasa etis atau bahasa yang dipergunakan dalam bidang moral dikaji secara logis. Metaetika menganalisis logika perbuatan dalam kaitan dengan "baik" atau "buruk". Perkembangan lebih lanjut dari metaetika ini adalah Filsafat Analitik.

Etika tidak hanya berkutat pada hal-hal teoritis, namun juga terkait erat dengan kehidupan konkret, oleh karena itu ada beberapa manfaat etika yang perlu diperhatikan dalam kaitannya dengan kehidupan konkret, yaitu:

1. Perkembangan hidup masyarakat yang semakin pluralistik menghadapkan manusia pada sekian banyak pandangan moral yang bermacam-macam, sehingga diperlukan refleksi kritis dari bidang etika. Contoh: etika medis tentang masalah aborsi, bayi tabung, kloning, dan lain-lain. 
MOKH. SYA'RONI:Etika Keilmuan

2. Gelombang modernisasi yang melanda di segala bidang kehidupan masyarakat, sehingga cara berpikir masyarakat pun ikut berubah. Misalnya: cara berpakaian, kebutuhan fasilitas hidup modern, dan lain-lain.

3. Etika juga menjadikan kita sanggup menghadapi ideologiideologi asing yang berebutan mempengaruhi kehidupan kita, agar tidak mudah terpancing. Artinya kita tidak boleh tergesagesa memeluk pandangan baru yang belum jelas, namun tidak pula tergesa-gesa menolak pandangan baru lantaran belum terbiasa.

4. Etika diperlukan oleh penganut agama manapun untuk menemukan dasar kemantapan dalam iman dan kepercayaan sekaligus memperluas wawasan terhadap semua dimensi kehidupan masyarakat yang selalu berubah. ${ }^{15}$

\section{Aliran-aliran Etika}

\section{Hedonisme}

Hedonisme bertolak dari pendirian bahwa menurut kodratnya manusia mengusahakan kenikmatan, yang dalam bahasa Yunani disebut "hedone"; dari kata inilah timbul istilah "hedonisme". Secara negatif usaha ini terungkap dalam sikap menghindari rasa sakit, dan secara positif terungkap dalam sikap mengejar apa saja yang dapat menimbulkan rasa nikmat. Namun hedonisme tidak sekadar menetapkan kenyataan kejiwaan ini, melainkan juga berpendapat bahwa kenikmatan benar-benar merupakan kebaikan yang paling berharga atau yang tertinggi bagi manusia, sehingga dengan demikian adalah baik baginya apabila mengusahakan kenikmatan. Seseorang dikatakan baik bila perilakunya dibiarkan ditentukan oleh pertanyaan bagaimana caranya agar dirinya memperoleh kenikmatan yang sebesar-besarnya; dengan bersikap dengan itu ia 
MOKH SYA'RONI:Etika Keilmuan

bukan hanya hidup sesuai dengan kodratnya, melainkan juga memenuhi tujuan hidupnya. ${ }^{16}$

Keberatan terhadap aliran ini tidak dapat dihindari, karena seperti telah dikatakan, hedonisme menjadikan tujuan hidup tergantung pada keadaan lahiriah, sedangkan kesusilaan berarti penentuan diri sendiri. Dengan kata lain, sifat susila suatu perbuatan tidak tergantung pada banyaknya kenikmatan yang dihasilkannya, melainkan tergantung pada kecenderungan batiniah yang merupakan asalnya. Di samping itu dalam hedonisme lenyaplah hubungan dengan pihak lain, yang merupakan ciri pengenal bagi kesusilaan. Setiap orang mengusahakan kenikmatan bagi dirinya masing-masing; barang siapa mengatakan bahwa orang seharusnya juga memberikan kenikmatan bagi orang lain, berarti mengakui ukuran yang berbeda dari ukuran kenikmatan. Dan bila ia tambahkan bahwa pengabdian kepada sesama manusia itu kalau perlu dengan mengorbankan kenikmatan bagi diri sendiri, maka sebagai seorang hedonis ia sepenuhnya akan mengalami pertentangan dengan dirinya sendiri. ${ }^{17}$

\section{Utilisme}

Aliran dijabarkan dari kata Latin "utilis", yang berarti bermanfaat. Utilisme mengatakan bahwa ciri pengenal kesusilaan ialah manfaat suatu perbuatan. Suatu perbuatan dikatakan baik, jika membawa manfaat, dikatakan buruk, jika menimbulkan mudarat. Utilisme tampil sebagai sistem etika yang telah berkembang, bahkan juga sebagai pendirian yang agak bersahaja mengenai hidup.Paham ini mengatakan bahwa orang baik ialah orang yang membawa manfaat, dan yang dimaksudkannya ialah agar setiap orang menjadikan dirinya membawa manfaat yang sebesar-besarnya. Tetapi dalam kenyataannya sesuatu yang bermanfaat tidak pernah berdiri sendiri; sesuatu hal senantiasa bermanfaat bagi sesuatu hal yang lain. Umpamanya, suatu obat bermanfaat untuk memulihkan kesehatan, sebuah kitab bermanfaat untuk dibaca, sejumlah barang 
tertentu bermanfaat bagi pertanian, dan sebagainya.Begitu pula kebalikannya, hal-hal yang merugikan.

Terdapat beberapa sanggahan keberatan-keberatan terhadap utilisme.Bahwa pengertian bermanfaat tidak cocok untuk dipakai sebagai dasar menyusun etika, karena sesuatu hal tidak pernah bermanfaat ditinjau secara tersendiri, melainkan yang bermanfaat selalu merupakan sarana untuk mencapai suatu tujuan. Dengan demikian suatu hal yang sama ditinjau dari satu segi dapat bermanfaat, sedangkan ditinjau dari segi lain merugikan; suatu obat, misalnya, dapat bermanfaat bagi orang yang sakit dan merugikan bagi orang yang sehat. ${ }^{18}$ Karena itu seseorang yang mengatakan bahwa sesuatu hal bermanfaat, justru mempunyai suatu tujuan tertentu, meskipun tidak dikatakannya dan mungkin ia tidak akan mengingat-ingatnya secara sengaja. ${ }^{19}$

\section{Deontologi}

Terdapat pandangan lain sistem etika lain yang tidak mengukur baik tidaknya suatu perbuatan berdasarkan hasilnya, melainkan semata-mata berdasarkan maksud si pelaku dalam melakukan perbuatan tersebut. Kita bisa mengatakan juga bahwa sistem ini tidak menyoroti tujuan yang dipilih bagi perbuatan atau keputusan kita, melainkan semata-mata wajib tidaknya perbuatan dan keputusan kita. Teori yang dimaksudkan ini biasanya disebut deontologi (kata Yunani deon berarti: apa yang harus dilakukan; kewajiban).

Yang menciptakan sistem moral ini adalah filsuf besar dari Jerman, Immanuel Kant (1724-1804). Pemikirannya tidak mudah tapi sangat berpengaruh, sehingga ia bisa dianggap sebagai salah seorang pemikir terbesar di bidang filsafat moral. Menurut Kant, yang bisa disebut baik dalam arti sesungguhnya hanyalah kehendak yang baik. Semua hal lain disebut baik secara terbatas atau dengan syarat. Kesehatan, kekayaan, atau inteligensi, misalnya, adalah baik, 
MOKH SYA'RONI:Etika Keilmuan

jika digunakan dengan baik oleh kehendak manusia, tapi jika dipakai oleh kehendak yang jahat semua hal itu bisa menjadi jelek sekali.Bahkan keutamaan-keutamaan bisa disalahgunakan oleh kehendak yang jahat.

Hakikat jawaban Kant ialah bahwa suatu kehendak sesuai dengan kewajiban apabila berdasarkan pertimbangan-pertimbangan (maksim-maksim) yang dapat diuniversalisasikan, artinya yang dapat kita kehendaki agar berlaku bukan hanya bagi kita sendiri, melainkan bagi siapa saja.Suatu maksim bersifat moral apabila dapat diuniversalisasikan (dijadikan hukum umum), amoral atau jahat, apabila tidak dapat diuniversalisasikan. Hal itu dirumuskan oleh Kant dalam apa yang disebutnya "imperatif kategoris". Prinsip penguniversalisasian itu adalah unsur kedua dalam etika Kant yang sangat berpengaruh terhadap etika selanjutnya.Kant mulai dengan menegaskan bahwa paham-paham moral tidak mungkin diperoleh dari pengalaman empiris-indrawi.Paham-paham moral bersifat apriori dan berdasarkan akal budi praktis, yaitu berdasarkan pengertian mengenai baik dan buruk yang mendahului segala pengalaman. $^{20}$

\section{E. Prinsip Dasar Etika Islam}

Agama adalah sumber nilai-nilai etika yang tak pernah kering, karena agama melihat hakikat manusia pada perbuatan baiknya.Dalam agama, tinggi rendah seseorang tidak ditentukan oleh harga, ilmu ataupun kekuasaan, tetapi ditentukan sepenuhnya oleh perbuatan baik atau taqwanya dan seberapa jauh nilai-nilai etika menjiwai dan mewarnai segala tindakannya. Oleh karena agama untuk manusia, dengan sendirinya etika menjadi salah satu ajaran yang amat penting dalam agama apapun, dan dari sudut pandangan etika, rasanya semua agama sepakat mempunyai pandangan yang sama, semua agama memerintahkan pemeluknya berbuat baik dan melarang berbuat jahat. 
Dari sini jelasbahwa al-Quran dan hadis sebagai sumber ajaran Islam dapat dijadikan acuan didalam seluruh aspek kehidupan manusiabaik sebagai makhluk individu maupun makhluk sosial. Didalam kehidupan sosial tentunya dibutuhkan adanya nilai-nilai yang mengatur kehidupan manusia sebagai anggota masyarakat. Hal inilah yang perlu dikaji tentang sejauhmana Islam meletakkan prinsip dasar etika sosial yang berhubungan dengan pembangunan, politik, ekonomi dan keilmuan yang semua itu merupakan aspekaspek dari kehidupan modern.

Perkembangan ilmu pengetahuan dan teknologi yang didasarkan atas nilai-nilai etika Islam akan dapat menunjang terwujudnya blue print (cetak biru) masa depan umat manusia. Hal itu disebabkan umat masa depan yang baik tidak akan kita jumpai pada situasi perkembangan ilmu pengetahuan dan teknologi saja, tetapi juga pada keyakinan manusia yang utuh terhadap kebenaran mutlak yang merupakan sumber segala sumber. Pada dasarnya sains adalah netral, namun dalam perkembangannya sains mempunyai tujuan untuk diterapkan,untuk memberikan tempat pada manusia sebagai penguasa alam, sehingga manusia bisa bebas mengeksploitasikannya demi kepentingan manusia sendiri dalam kehidupan sehari-hari.

Etika, menurut Isma'il Raji al-Faruqi, tidak dapat dipisahkan dari agama dan justru mesti dibangun di atasnya.Sebagai bagian dari ajaran Islam, etika harus berasaskan pada prinsip kesatupaduan kebenaran dan bersumber pada prinsip keesaan Allah. Dia mengatakan sebagai berikut:

Dalam Islam, etika tak dapat dipisahkan dari agama dan dibangun sepenuhnya di atasnya. Pikiran Islam tidak mengenal pasangan kata yang bertentangan seperti "religius-sekuler", "sakralprofan", "gereja-negara"; dan bahasa Arab, bahasa Islam, tidak punya padanan bagi istilah-istilah tersebut. Prinsip pertama pengetahuan Islam karenanya adalah kesatupaduan, kebenaran, sebagaimana halnya prinsip pertama kehidupan manusia adalah kesatupaduan 
MOKH SYA'RONI:Etika Keilmuan

persona dan prinsip realitas adalah keesaan Allah. Ketiga kesatuan ini merupakan aspek-aspek dan tidak bisa dipisahkan satu sama lain. kesatuan ini adalah prinsip tertinggi.21

Allah adalah inti kenormativan di mana gerakan-gerakan-Nya, ajaran-ajaran dan keharusan yang apabila hal itu telah dipahami dan disadari oleh seseorang, maka ia akan merasakan adanya kewajiban yang timbul darinya. ${ }^{22}$ Allah adalah pencipta segala yang ada, penguasa, pemikir, pemelihara, hakim, dan pelaksana. Kehendak-Nya adalah hukum dalam alam dan dalam perilaku manusia. ${ }^{23} \mathrm{Pe}-$ nempatan Allah sebagai inti kenormativan, yang kehendak-Nya teraktualisasikan dalam nilai-nilai moral sebagai norma perilaku manusia, telah memberikan warna kepada model etika.Secara umum, etika yang dikonsepkan oleh Isma'il Raji al-Faruqi itu dapat dikategorikan ke dalam etika wahyu, yaitu suatu etika yang berpandangan bahwa ukuran moral (baik-buruk) senantiasa didasarkan kepada kitab wahyu Allah. Atau, bila mengikuti klasifikasi Majid Fahry dalam bukunya Ethical Theories In Islam, modal pandangan etika Isma'il Raji al-Faruqi tersebut bisa dimasukkan pada bahasan "etika religius". Dalam etika religius ini, teori-teorinya berakar pada konsepsi al-Qurantentang manusia dan kedudukannya di alam semesta.

Etika al-Quran adalah sebagian dari sebagian dari etika dunia dan agama yang diharapkan dapat menjawab harapan dan optimisme. Mampukah etika al-Quran menjawabnya atau setidaknya bertahan di tengah kompleksitas dan relativitas multikulturalisme, menarik untuk ditelusuri lebih dalam.

Etika al-Quran dalam pembahasan ini hanya terbatas pada konsep etika al-Quran sebagaimana diuraikan oleh Toshihiko Izutsu, yang oleh Majid Fakhry disebut sebagai etika skriptural. ${ }^{24}$ Sedangkan menurut Toshihiko Izutsu, konsep etika al-Quran dapat dapat direpresentasikan dalam istilah yang disebutnya sebagai ethico 
MOKH. SYA'RONI:Etika Keilmuan

religiuos consepts in the Qur'an. Konsep-konsep tersebut meliputi istilah-istilah șāliḥ, birr, ma'rūf, khayr danhasan. ${ }^{25}$

\section{Al-Sāàlih}

Kata șāliḥmenurut Izutsu merupakan istilah-istilah yang paling umum dipakai sebagai ungkapan etika religius dalam al-Quran. Tidak ada yang menunjukkan karakter religius tentang konsep kebaikan moral yang secara empatik lebih baik dari pada kata șāliḥ. Kata șālih secara umum diartikan sebagai "kebajikan" (righteous).

Kata șāliḥ ini paling sering terangkai dengan kata ìmān. Tidak kurang dari lima puluh ayat, kata immān terangkai dengan kata șāliḥ khususnya dalam kalimat "orang-orang yang beriman dan beramal saleh (good works)". Dari sini dapat dikatakan bahwa șālih merupakan manifestasi dari iman, iman menjadi tidak bermakna tanpa kesalihan. ${ }^{26}$

\section{Al-Birr}

Kata birr adalah satu dari sekian banyak kata yang merupakan ungkapan etika keagamaan dalam al-Quran. Izutsu menyebutnya sebagai istilah moral al-Quran yang paling sulit dipahami (the most elusive of the Qur'anic moral terms).Istilah birr memiliki makna yang strategis bagi upaya pengembangan keshalihan sosial dalam Islam.Hal ini dapat dilihat dari maknanya yang tidak saja berdimensi kebaikan vertikal (the act of rendering religious service to God). Tetapi juga berdimensi horisontal (emphasis to justice and love in social life).Bahkan maknanya disejajarkan dengan ketakwaan (fear of God) dan kedermawanan (almsgiving). ${ }^{27}$

Paling tidak terdapat 6 (enam) ayat yang di dalamnya terdapat kata birr ini; masing-masing dalam QS. Al-Baqarah [2]: 44,177, dan 189, Ali Imran [3]: 92, al-Mā'idah [5]: 2 dan al-Mujādilah [58]: 9. Tosihiko Izutsu mengatakan bahwa makna kata birr ini sangat variatif. Penerjemahan kata ini dalam bahasa Inggris adalah piety (kesalihan) dan righteousness (kebajikan). 
MOKH SYA'RONI:Etika Keilmuan

\section{Al-Ma'rūf}

Akar kata ma'rūf adalah 'arafayang berarti "mengetahui" (to know), mengenal dan mengetahui (to recognize), melihat dengan tajam. Sebagai kata benda maka ma'ruf berarti yang diketahui, yang dikenal atau diketahui, patut atau pantas secara nalar "baik" (good), apa yang diakui diterima oleh hukum Allah (what is a knowlegde and approved by divine law). Karena makna akar kata ini "mengetahui" maka ma'ruf dalam konteknya memiliki makna kebaikan dan dikenal oleh masyarakat setempat bahkan akar kata ini mirip dengan urf yang berarti adat kebiasaan. Dari penggunaan kata ini menujukan bahwa al-Quran mengadopsi terminologi moral kesukuan dan menjadikannya bagian integral dan sistem etika baru.

Lebih jauh Toshihiko mengatakan bahwa $m a^{\prime} r u \bar{f}$ secara harfiah berarti diketahui (know) yaitu apa yang dipandang sebagai diketahui dan dikenal. Dengan demikian secara sosial diterima. Anti tesisnya yaitu munkar yang berati apa yang tidak diterima dengan baik karena hal itu tidak diketahui /asing. Masyarakat kesukuan Arab jahiliyah akan memandang hal yang dikenal dan diketahui sebagai hal yang baik ( $m a^{\prime} r u \bar{f}$ ) dan sesuatu yang asing (tak dikenal) sebagai hal yang buruk (munkar).

$M a^{\prime} r u \bar{f}$ secara formal bertentangan dengan munkar yang secara harfiyah berarti tidak diketahui (unknown), asing (foreign), tidak diterima (disapproved) dan buruk (bad). Al-Quran berkalikali mengingatkan Nabi dan orang-orang yang beriman dengan penekanan yang kuat untuk mengajak $m a^{\prime} r u \bar{f}$, dan mencegah yang munkar. Dalam bentuk kombinasi ini kedua istilah ini nampak mengandung ide umum dan komprehansif yaitu baik, dan buruk secara religius. $M a^{\prime} r u ̈ f$ berarti tindakan apapun yang muncul dari dan sesuai dengan keyakinan yang sebenar-benarnya dan munkar adalah perbuatan yang bertentangan dengan perintah Allah. ${ }^{28}$ 


\section{Al-Khayr}

Kata ini juga paling dekat dengan makna baik (good), juga memiliki makna yang terkait dengan harta, yaitu harta sebagaimana terdapat dalam QS. al-Baqarah [2]: 237. Pada level kedua khayr memiliki makna sebagai karunia Tuhan (God's bounty), rahmat Tuhan/wahyu (God special favour/revelation), keimanan dan keyakinan yang tulus (belief genuine faith), perbuatan baik/salihat (good work) dan kualitas kebaikan mukmin (excellent believer).

Kebaikan dalam konteks khayr memiliki dua dimensi yakni kebaikan ilahiyah (kebaikan yang berasal dari Tuhan) dan kebaikan insaniyah (kebaikan yang berasal dari manusia). Kata itu berarti sesuatu yang dinilai dengan benar sebagai hal yang bernilai jika dilihat dari sudut pandang agama yang diwahyukan. ${ }^{29}$

\section{Al-Ḥasan/Ḥasanah}

Hasandigunakan untuk pengertian menguntungkan dalam masalah usaha atau perdagangan. Al-Quran menggunakan kata ini secara viguratif dalam hubungannya dengan perbuatan. Dengan berbuat baik manusia memberikan dagangan yang banyak bagi Allah. Sebagaimana terlihat QS. al-Baqarah dan al-Hadīd [57]:18. ${ }^{30}$

\section{F. Etika Keilmuan}

Tidak dapat dielakkan lagi bahwa ilmu dan teknologi telah banyak membantu manusia dalam pengertian yang sangat luas, tetapi juga tidak dapat diabaikan begitu saja adanya dampak negatif. Dalam hal ini manusia tidak seharusnya menjadi budak teknologi, tetapi ilmu dan teknologi yang harus berada di tangan manusia atau di bawah kendali manusia. Dengan demikian illmu dan teknologi dapat dikembangkan oleh dan bagi manusia untuk kepentingan kesejahteraan manusia.

Dalam pandangan AGM Van Nelsen, ilmu dikembangkan pada mulanya sebagai teori yaitu untuk mendalami pengertian diri 
MOKH SYA'RONI:Etika Keilmuan

manusia dan alam sekitar, sehingga manusia sampai pada inti dirinya. Pada tahap ini ilmu manusia lebih bersifat mendeskrispsikan realitas. Ilmu pengetahuan dimaksudkan agar manusia mampu menjadi manusia yang sungguh-sungguh menyadari diri dan kedudukannya yang unik dalam kosmos. ${ }^{31}$ Dalam hal ini problem etis ilmu pengetahuan adalah menyangkut adanya keteganganketegangan antara realitas yang ada (das sein) dan relitas yang seharusnya ada (das solen). ${ }^{32}$

Selanjutnya perkembangan ilmu dan teknologi dalam obyektifitas dan otonominya tidak mungkin lepas dari pengaruh pola-pola kebudayaan dan praanggapan di luar kegiatan keilmuan. Dengan demikian tidak berlebihan jika manusia dituntut harus mampu mengendalikan dan bertanggungjawab atas ilmu pengetahuan dan teknologi sebagai ciptaannya dan itu justru demi keselamatan, kelestarian kehidupannya sendiri.

Kebenaran intelektual yang ada pada ilmu bukanlah suatu efek dari keterlibatan ilmu dengan bidang-bidang kehidupan. Kebenaran memang merupakan ciri asli dari ilmu itu sendiri. Dengan demikian maka pengabdian ilmu secara netral, tak berwarna, dapat melunturkan pengertian kebenaran, sehingga ilmu terpaksa menjadi steril.Uraian keilmuan tentang masyarakat sudah semestinya harus diperkuat oleh kesadaran terhadap berakarnya kebenaran.

Ilmu bukan tujuan tetapi sarana, karena hasrat akan kebenaran itu berimpit dengan etika pelayanan bagi sesama manusia dan tanggungjawab secara agama. Sebenarnya ilmuwan dalam gerak kerjanya tak usah memperhitungkan adanya dua faktor: ilmu dan tanggungjawab, karena yang kedua itu sudah lengket dengan yang pertama.

Ilmu pun lengket dengan keberadaan manusia yang transenden dengan kata-kata lain, keresahan ilmu bertalian dengan hasrat yang terdapat dalam diri manusia. Di situ terdapat petunjuk 
mengenai kebenaran yang transenden.Dengan ini berarti pula bahwa titik henti dari kebenaran itu terdapat di luar jangkauan manusia. ${ }^{33}$

Tanggung jawab etis merupakan hal yang menyangkut kegiatan maupun penggunaan ilmu. Dalam kaitan ini terjadi keharusan untuk memperhatikan kodrat manusia, martabat manusia, menjaga keseimbangan ekosistem, bertanggung jawab ada kepentingan umum, kepentingan generasi mendatng dan bersifat universal. Karena pada dasarnya ilmu pengetahuan adalah untuk mengembangkan dan memperkokoh eksistensi manusia bukan untuk menghancurkan eksistensi manusia.

Tanggung jawab etis ini bukanlah berkehendak mencampuri atau bahkan menghancurkan otonomi ilmu, tetapi bahkan dapat sebagai umpan balik bagi pengembangan ilmu itu sendiri yang sekaligus akan lebih memperkokoh eksistensi manusia. Tanggung jawab etis semacam ini pada akhirnya bertujuan agar manusia terinspirasi, termotivasi dan terpacu mengembangkan ilmu untuk kemaslahatan umat dan bukan untuk mencelakakan diri dan generasinya. ${ }^{34}$

Dalam realitas kehidupan masyarakat dewasa ini, terjadi konflik antara etika pragmatik dengan etika pembebasan manusia. Etika pragmatik berorientasi pada kepentingan-kepentingan elite sebagai wujud kerja sama antara iptek, uang, kekuasaan dan kekerasan yang cenderung menindas untuk kepentingannya sendiri yang bersifat materialistik, dengan etika pembebasan manusia dari penindasan kekuatan elite, etika pembebasan yang bersifat spiritual dan universal.

Etika pembebasan manusia, yang bersifat spiritual dan universal itu, bisa muncul dari kalangan ilmuwan itu sendiri, yang bisa jadi karena tidak kerasan dan menolak etika pragmatik yang dirasakan telah menodai prinsip-prinsip ilmu yang menjunjung tinggi kebenaran, kebebasan dan kemandirian.Ilmuwan ini biasanya 
MOKH SYA'RONI:Etika Keilmuan

bekerjasama dengan para rohaniawan dan rakyat kecil pada umumnya, menjadi sebuah gerakan perlawanan terhadap berlangsungnya etika pragmatik yang bertumpu pada kekuasaan birokrasi politik yang sudah mapan. ${ }^{35}$

Usaha untuk menghindarkan dampak negative dari perkembangan ilmu pengetahuan dan teknologi ini diperlukan adanya kode etik yang bersifat universal sehingga kemajuan ilmu pengetahuan dan teknologi dapat diterima oleh semua pihak, tanpa harus mengorbankan pihak-pihak lain dan tanpa merusak lingkungan, serta tanpa adanya kejahatan intelektual. Berbagai kajian Islam muncul untuk merumuskan etika keilmuan,sehingga perkembangan ilmu pengetahuan dan teknologi betul-betul utuh. Konsep sains yang utuh setidaknya harus memiliki tiga karakter pokok :

a. Sains harus berorientasi kepada dasar nilai-nilai. Nilai-nilai ini dapat ditemukan melalui metode ilmiah atau wahyu yang dihubungkan dengan konsep segitiga piramida,yaitu Allah swt, manusia, dan alam.

b. Dengan sains Islami, perkembangan ilmu pengetahuan akan memiliki tujuan yang berorientasi pada nilai, dan membangkitkan dirinya pada pembaharuan masyarakat yang bergerak kedepan melalui penemuan ilmiah.

c. Sains Islami,yang berada didalam maupun diluar lembaga struktural,harus berguna bagi tujuan-tujuan tertentu yang sesuai dengan kebenaran untuk menunjang perubahan dan pembangunan serta membantu perbaikan manusia. ${ }^{36}$

\section{E. Penutup}

Pengembangan ilmu pengetahuan sebagai perwujudan aksiologi ilmu mengharuskan visi etik yang tepat untuk diaplikasikan. Manusia dengan ilmu pengetahuan akan mampu berbuat apa 
saja yang diinginkan, namun pertimbangannya tidak hanya pada apa yang dapat diperbuat oleh manusia. Yang lebih penting pada konteks ini adalah perlunya pertimbangan etik apa yang harus dilakukan dengan tujuan kebaikan manusia.

Sebenarnya mengupayakan rumusan konsep etika dalam ilmu idealnya harus sampai pada rumusan normatif yang berupa pedoman konkrit bagaimana tindakan manusia di bidang ilmu harus dilakukan. Jika hanya rumusan berada pada dataran etika yang abstrak, akan terdapat kesulitan ketika diterapkan terhadap masalah yang bersifat konkrit. [

\section{Catatan Akhir}

1Jujun S. Suriasumantri, Ilmu dalam Perspektif, Jakarta: Yayasan Obor Indonesia, 2006, h. 3

2Ibid., h. 2.

${ }^{3}$ Abbas Hamami, "Etika Keilmuan", dalam Tim Dosen Filsafat Ilmu, Filsafat Ilmu, Yogyakarta: Liberty, 1996, h. 155.

4Jujun S.Suriasumantri, IImu, h. 35.

5Abbas Hamami, "Etika Keilmuan",h. 161-162.

6Frans Magnis Suseno,Etika Dasar Masalah-Masalah Pokok Filsafat Moral,Yogyakarta: Kanisius,1989,h.15

${ }^{7}$ K. Bertens, Etika, Jakarta: Gramedia, 2007, h. 4.

${ }^{8}$ A.P Cowie (ed.), Oxford Learner's Pocked Dictionary, Oxford: Oxford University Press, 1987, h. 127.

9 Victoria Neufeld (ed.), Webster's New World Dictionary, Third Edition, New York: Simon \& Schuster Macmillan Company, 1999, h. 400 .

10William Lillie, an Introduction to Ethics, New York: Barnes Nable, 1957, h. 1

${ }^{11}$ H. De Vos, Pengantar Etika, Yogyakarta: Tiara Wacana, 1987, h.

1.

12Franz Magnis Suseno, Etika Dasar,h. 14.

${ }^{13}$ A.Susanto,Filsafat Ilmu:Suatu Kajian dalam Dimensi Ontologis, Epistimologisdan Aksiologis,Jakarta: Bumi Aksara,2011,h.172 
${ }^{14}$ Rizal Mustansyir dan MisnalMunir, Filsafat Ilmu, Yogyakarta: Pustaka Pelajar, 2001, h. 29.

15K. Bertens, Etika, h. 15-22.

16H. De. Vos, Pengantar Etika, Yogyakarta: Tiara Wacana, 2002, h. 161.

17Ibid., h. 166-167.

18Ibid., h. 181.

19Ibid., h. 186-187.

${ }^{20}$ Franz Magnis Suseno, 13 Model Pendekatan Etika, Yogyakarta: Kanisius, 2006, h. 137.

21Isma'il Raji al-Faruqi, Tawhid its Implication for Thought and Life, Kuala Lumpur: Polygraphie Sdn, 1982, h. 64.

${ }^{22}$ Majid Fakhry, Etika dalam Islam, terj. Zakiyudin Baidhowy, Yogyakarta: Pustaka Pelajar, 1996, h. 1.

23Ibid., h. xxii

${ }^{24}$ Ibid., h. 1

${ }^{25}$ Toshihiko Izutsu, Ethico Religious Concepts in the Qur'an, Canada: McGill University Press, 1966, h. 203.

${ }^{26}$ Ibid., h. 204.

27Ibid., h. 207-208.

${ }^{28}$ Ibid, h. 213-214.

29Ibid, h. 220.

30Ibid, h. 221.

31A.G.M. van Melsen, Ilmu Pengetahuan dan Tanggung Jawab Kita, terj. K. Bertens, Jakarta: Gramedia, 1992, h. 4-5.

32Ibid., h. 72.

33Jujun S. Suriasumantri, Ilmu, h. 235-236.

${ }^{34}$ Achmad Charris Zubair, Dimensi Etik dan Asketik Ilmu Pengetahuan Manusia Kajian Filsafat Ilmu, LESFI, Yogyakarta, 2002, h. 49.

35Musa Asy'arie, Filsafat Islam Sunnah Nabi dalam Berpikir, LESPI, Yogyakarta, 2002, h. 85.

${ }^{36}$ A.M.Saefuddin A.M. et al., Desekularisasi Pemikiran,Bandung: Mizan,1987, h.60. 


\section{DAFTAR PUSTAKA}

Amin, Ahmad, Etika Ilmu Akhlaq, Jakarta: Bulan Bintang, 1996.

Asy'arie, Musa, Filsafat Islam Sunnah Nabi dalam Berpikir, Yogyakarta: LESPI, 2002.

Bakhtiar, Amsal,Filsafat Ilmu, Jakarta: Raja Grafindo Persada, 2004.

Bertens, K., Etika, Jakarta: Gramedia, 2007.

Cowie, A.P. (ed.), Oxford Learner's Pocked Dictionary, Oxford: Oxford University Press, 1987.

Fakhry, Madjid, Etika dalam Islam, terj. Zakiyuddin Baidlowy, Yogyakarta: Pustaka Pelajar, 1996.

Faruqi, Isma'il Raji,Tawhid its Implication for Thought and Life, Kuala Lumpur: Polygraphie Sdn, 1982.

Hamami, Abbas, "Etika Keilmuan”, dalam Tim Dosen Filsafat Ilmu, Filsafat Ilmu, Yogyakarta: Liberty, 1996.

Izutsu, Toshihiko, Ethico Religious Concepts in the Qur'an, Canada: McGill University Press, 1966.

Lillie, William, An Introduction to Ethics, New York: Barnes Nable,1957.

M. Amin Abdullah, Falsafah Kalam di Era Postmodern, Yogyakarta: Pustaka Pelajar, 1997.

Melsen, A.G. M van,Ilmu Pengetahuan dan Tanggung Jawab Kita, terj. K. Bertens, Jakarta: Gramedia, 1992.

Muhadjir, Noeng, Filsafat Ilmu, Yogyakarta: Rake Sarasin, 1998.

Mustansyir, Rizal, dan MisnalMunir, Filsafat Ilmu, Yogyakarta: Pustaka Pelajar, , 2001.

Neufeld, Victoria (ed.), Webster's New World Dictionary, Third Edition, New York: Simon \& Schuster Macmillan Company, 1999. 
Saefuddin, A.M., et al., Desekularisasi Pemikiran,Bandung: Mizan, 1987.

Suriasumantri, JuJun S., Ilmu dalam Perspektif, Jakarta: Yayasan Obor Indonesia, 2006.

Susanto,A., Filsafat Ilmu :Suatu Kajian dalam Dimensi Ontologis, Epistimologisdan Aksiologis,Jakarta: Bumi Aksara,2011.

Suseno,Frans Magnis, Etika Dasar Masalah-Masalah Pokok Filsafat Moral,Yogyakarta: Kanisius,1989.

Suseno,Frans Magnis, Etika Jawa, Jakarta: Gramedia, 1993.

Tjahjadi, SP. Lili, Hukum Moral, Yogyakarta: Kanisius, 1991.

Vos, H. De, Pengantar Etika,Yogyakarta: Tiara Wacana, 2002.

Zubair, Achmad Charris,Dimensi Etik dan Asketik Ilmu Pengetahuan Manusia Kajian Filsafat Ilmu, Yogyakarta: LESFI, 2002. 